\title{
Porphyromonas macacae comb. nov., a Consequence of Bacteroides macacae Being a Senior Synonym of Porphyromonas salivosa
}

\author{
DARIA N. LOVE* \\ Department of Veterinary Pathology, University of Sydney, New South Wales 2006 Australia
}

\begin{abstract}
DNA-DNA hybridization studies were performed with members of the genus Porphyromonas. Porphyromonas salivosa $\mathrm{NCTC} 11632^{\mathrm{T}}$ ( $\mathrm{T}=$ type strain) exhibited an average level of intraspecies DNA-DNA hybridization with VPB 3313 and VPB 3444 of 95\% and an average level of DNA-DNA hybridization with Bacteroides macacae ATCC $33141^{\mathrm{T}}$ of $81 \%$. However, while the cat strains and monkey strain which I studied exhibited sufficient hybridization to be considered members of a single species, the tight DNA hybridization clustering and phenotypic differences suggested that the biovars isolated from cats and monkeys are distinct and can be recognized by colonial and growth characteristics, lipase activity, sorbitol utilization, proteinase patterns, and whole-cell protein profiles on sodium dodecyl sulfate-polyacrylamide gel electrophoresis gels. As B. macacae is a senior synonym of $\boldsymbol{P}$. salivosa, Porphyromonas macacae comb. nov. is proposed.
\end{abstract}

In 1987 Love et al. (10) described Bacteroides salivosus as a pigmented asaccharolytic pathogen which was isolated from subcutaneous abscesses and pyothoraxes of cats. The $B$. salivosus strains exhibited little DNA-DNA hybridization with members of previously described pigmented asaccharolytic Bacteroides species. Also, original DNA-DNA hybridization experiments revealed that the levels of hybridization between feline strains and Bacteroides macacae ATCC $33141^{\mathbf{T}}(\mathrm{T}=$ type strain) $(2,17)$ were not significant. These findings and the reported fermentation of a limited number of sugars by $B$. macacae resulted in $B$. macacae not being included in the final studies in which $B$. salivosus was described. In 1992, the latter species was reassigned to the genus Porphyromonas as Porphyromonas salivosa (9). However, since that time, workers in two laboratories $(6,13 \mathrm{a})$ have reported that $P$. salivosa NCTC $11632^{\mathrm{T}}$ ferments glucose, lactose, and sucrose in prereduced anaerobically sterilized media, and Paster et al. (15) have shown that $P$. salivosa NCTC $11632^{\mathrm{T}}$ exhibits $99.3 \%$ rRNA sequence homology with $B$. macacae ATCC $33141^{\mathrm{T}}$. In this paper I describe the results of DNA relatedness studies performed with $P$. salivosa strains isolated from cats and of a comparison of these strains with $B$. macacae ATCC $33141^{\mathrm{T}}$ (obtained from H. Jousimies-Somer). Below I propose that $B$. macacae should be assigned to the genus Porphyromonas, as Porphyromonas macacae comb. nov.

\section{MATERIALS AND METHODS}

Bacterial strains. All of the strains used in this study are shown in Table 1. Growth conditions and biochemical methods. The growth conditions and biochemical methods used in this study have been described previously (1, 10-12). Cells for sodium dodecyl sulfate (SDS)-polyacrylamide gel electrophoresis (PAGE) were grown anaerobically for 3 days on 5\% defibrinated sheep blood agar plates (blood agar base no. 2; Oxoid, Ltd., Basingstoke, England) containing additional hemin and menadione, formate and fumarate (4), and proteose peptone (1.5\%, wt/vol; Difco Laboratories, Detroit, Mich.) in the presence of a streak of Staphylococcus epidermidis to enhance growth and pigmentation. $P$. salivosa NCTC $11632^{\mathrm{T}}$ and B. macacae ATCC $33141^{\mathrm{T}}$ were grown on similar plates with and without a streak of $S$. epidermidis for comparisons of growth rate and colonial characteristics.

DNA hybridization. DNA was isolated essentially as described previously (13). Small amounts $(5 \mu \mathrm{g})$ of fragmented and denatured DNA were labeled with ${ }^{125} \mathrm{I}$

* Phone: 61-2-692 2454. Fax: 61-2-552 6526. Electronic mail address: suvp00@angis.su.oz.au. by using a variation of the thallium chloride method $(16,18)$. The S1 nuclease procedure was used to estimate percentages of hybridization as described by Johnson (5). Background reassociation values and the amounts of S1 nucleaseresistant material in the labeled preparations were determined after denatured unlabeled bacterial DNA was replaced with $50 \mu \mathrm{l}(20 \mu \mathrm{g})$ of sheared native salmon sperm DNA. Results were recorded as the means of three determinations by using DNAs extracted from two different batches of cells on separate occasions; each DNA preparation was iodinated on two occasions.

SDS-PAGE of whole-cell proteins. Cells grown for 5 days were harvested from plates and washed in sterile water before lysis in sample buffer containing (final concentrations) $4 \%$ SDS, $20 \%$ glycerol, $100 \mathrm{mM}$ dithiothreitol, and $125 \mathrm{mM}$ Tris- $\mathrm{HCl}(\mathrm{pH} 7.8)$. Preparations were electrophoresed on $12 \%$ acrylamide gels, and SDS-PAGE (7) was carried out with a Hoefer Mighty Small II apparatus (Hoefer Scientific Instruments, San Francisco, Calif.).

SDS.PAGE detection of proteinase activity. The modified method of North et al. (14) was used for SDS-PAGE detection of proteinase activity. Briefly, gelatin (final concentration, $0.05 \%$, wt $/ \mathrm{vol}$ ) was added to $7.5 \%$ polyacrylamide, and polymerization was allowed to proceed normally. Washed $P$. salivosa NCTC $11632^{\mathrm{T}}$ and $B$. macacae ATCC $33141^{\mathrm{T}}$ cells harvested as described above after 5 days of growth on plates containing $S$. epidermidis were sonicated in a Cup Horn (three bursts [ $3 \mathrm{~min}$ each] at $60 \%$ duty cycle; output, 6 ) and a model W-375 cell disruptor (Heat Systems Ultrasonics, Inc.). Sucrose (final concentration, 10\%) was added to crude cell extracts (which were clarified by centrifugation at 30,000 $\times g$ for $30 \mathrm{~min}$ at $4^{\circ} \mathrm{C}$ ), and electrophoresis was carried out at room temperature at a constant voltage of $130 \mathrm{~V}$ until completion. The gel was gently washed in distilled water containing $2.5 \%$ (vol/vol) Triton X-100 for $1 \mathrm{~h}$ with four changes of solution before incubation overnight at $22^{\circ} \mathrm{C}$ in $10 \mathrm{ml}$ of $100 \mathrm{mM}$ Tris- $\mathrm{HCl}(\mathrm{pH}$ 8 ). Cysteine was added to a final concentration of $50 \mathrm{mM}$ (to ensure optimal reduction and activity of proteinases), and the gel was incubated for an additional $1.5 \mathrm{~h}$ before it was stained with $0.025 \%$ (wt/vol) Coomassie brilliant blue R-250 in $7.5 \%$ (vol $/ \mathrm{vol}$ ) acetic acid-10\% ( $\mathrm{vol} / \mathrm{vol}$ ) methanol. After $2 \mathrm{~h}$, the gel was destained in $10 \%$ ( $\mathrm{vol} / \mathrm{vol})$ acetic acid, and proteolytic activity was visualized as a clear band against a blue background.

\section{RESULTS AND DISCUSSION}

Colonies of $B$. macacae ATCC $33141^{\mathrm{T}}$ were 0.1 to $0.2 \mathrm{~mm}$ in diameter, entire, and dome shaped after 6 days of incubation on blood agar plates. After 9 days in the presence of $S$. epidermidis, however, the colonies were 1.0 to $1.5 \mathrm{~mm}$ in diameter, entire, umbonate with a central depression, and creamy brown. As incubation progressed and where colonies were crowded, each colony surface was wrinkled with multiple central depressions and peripheral ridging. In contrast, after 6 days of incubation, cat strain NCTC $11641^{\mathrm{T}}$ produced pinpoint colonies, but these colonies were consistently larger colonies than $B$. macacae ATCC $33141^{\mathrm{T}}$ colonies. After 9 days in the presence of $S$. epidermidis, the NCTC $11641^{\mathrm{T}}$ colonies were 1.0 $\mathrm{mm}$ in diameter, entire, high domed shaped, smooth, and creamy brown. The colonies did not become wrinkled or 
TABLE 1. Levels of DNA-DNA hybridization for $P$. salivosa and $P$. macacae comb. nov. with type strains of Porphyromonas species and members of the Porphyromonas rRNA cluster

\begin{tabular}{|c|c|c|c|}
\hline \multicolumn{2}{|c|}{ Source of unlabeled DNA } & \multicolumn{2}{|c|}{$\begin{array}{l}\text { \% Hybridization with } \\
\text { labeled DNA from }{ }^{a} \text { : }\end{array}$} \\
\hline Species or group & Strain & $\begin{array}{l}\text { P. salivosa } \\
\text { NCTC } \\
11632^{\mathrm{T}}\end{array}$ & $\begin{array}{l}\text { P. macaca } \\
\text { ATCC } \\
33141^{\mathrm{T}}\end{array}$ \\
\hline \multirow[t]{3}{*}{$P$. salivosa } & NCTC $11632^{\mathrm{T}}$ & 100 & 83 \\
\hline & VPB 3313 & 95 & 79 \\
\hline & VPB 3444 & 94 & 81 \\
\hline $\begin{array}{l}\text { P. macacae } \\
\text { comb. nov. }\end{array}$ & ATCC $33141^{\mathrm{T}}$ & 84 & 100 \\
\hline$P$. gingivalis & $\operatorname{ATCC} 33277^{\mathrm{T}}$ & 7 & 0 \\
\hline $\begin{array}{l}P \text {. gingivalis cat } \\
\text { strain }\end{array}$ & VPB 3492 & 23 & 5 \\
\hline P. circumdentaria & NCTC $12469^{\mathrm{T}}$ & 8 & 1 \\
\hline P. canoris & NCTC $12835^{\mathrm{T}}$ & 5 & 8 \\
\hline P. endodontalis & ATCC $35406^{\mathrm{T}}$ & 3 & 1 \\
\hline$P$. asaccharolytica & ATCC $25260^{\mathrm{T}}$ & $<1$ & 3 \\
\hline Bacteroides levii & ATCC $29147^{\mathrm{T}}$ & $<1$ & 4 \\
\hline
\end{tabular}

${ }^{a}$ The reference values were normalized to $100 \%$.

display depressions after more incubation or where crowding occurred.

The whole-cell protein and proteinase profiles on SDSPAGE gels for $B$. macacae ATCC $33142^{\mathrm{T}}$ and $P$. salivosa are shown in Fig. 1.

My DNA-DNA hybridization results (Table 1) showed that cat strains NCTC $11632^{\mathrm{T}}$, VPB 3313, and VPB 3444 exhibited negligible levels of hybridization with all of the other strains tested except the $B$. macacae strain. As the level of DNA-DNA hybridization was sufficient to consider $B$. macacae and $P$. salivosa members of the same species, $P$. salivosa is a later synonym of $B$. macacae.

My hybridization data, the findings of Paster et al. (15) that B. macacae ATCC $33141^{\mathrm{T}}$ and $P$. salivosa $\mathrm{NCTC} 11632^{\mathrm{T}}$ exhibited $99.3 \%$ rRNA homology and were deeply embedded

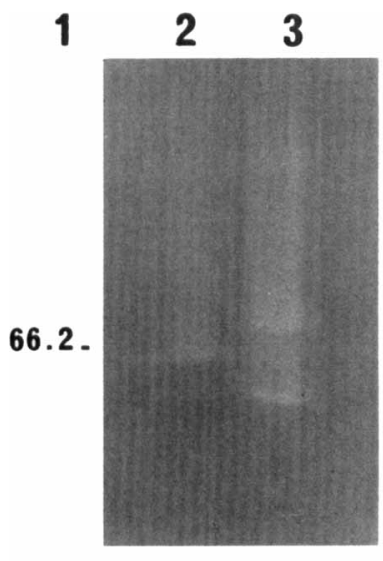

A

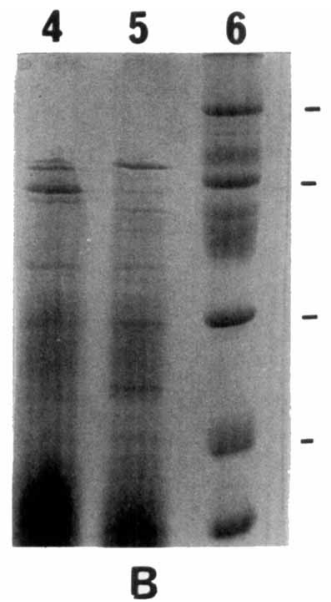

97.4
FIG. 1. (A) SDS-7.5\% PAGE gel containing $0.05 \%$ gelatin stained with Coomassie blue after development for proteinase activity. Lane 1, molecular mass (kilodaltons) indicates area of activity of proteinases; lane 2, $P$. salivosa NCTC $11632^{\mathrm{T}}$; lane $3, P$. macacae ATCC $33141^{\mathrm{T}}$. (B) SDS-12\% PAGE gel of whole-cell proteins denatured in sample buffer (4\% SDS, $20 \%$ glycerol, $100 \mathrm{mM}$ dithiothreitol, $125 \mathrm{mM}$ Tris- $\mathrm{HCl}$ [pH 6.8]) and stained with Coomassie blue Lane 4, $P$. salivosa $\mathrm{NCTC} 11632^{\mathrm{T}}$; lane $5, P$. macacae ATCC $33141^{\mathrm{T}}$; lane 6 , molecular mass markers (in kilodaltons). in the Porphyromonas rRNA cluster, and the presence of 13-methyltetradecanoic acid as a major cellular fatty acid $(8 ;$ unpublished data) provide compelling evidence that $B$. macacae ATCC $33141^{\mathrm{T}}$ should be transferred to the genus Porphyromonas as Porphyromonas macacae comb. nov.

An emended generalized description of this taxon based on my data and data in previous reports $(1,2,9,10,17)$ is given below.

Emended description of Porphyromonas macacae comb. nov. Cells are anaerobic, nonsporing, nonmotile, gram-negative rods or coccoid forms. After 6 days on blood agar plates, colonies of $P$. macacae ATCC $33141^{\mathrm{T}}$ are 0.1 to $0.2 \mathrm{~mm}$ in diameter, entire, and dome shaped. After 9 days in the presence of $S$. epidermidis, however, the colonies are 1.0 to 1.5 $\mathrm{mm}$ in diameter, entire, umbonate with a central depression, and creamy brown. As incubation progresses and where colonies are crowded, the surfaces of colonies may become wrinkled with multiple central depressions and peripheral ridging. Colonies do not fluoresce under UV light (265 and $366 \mathrm{~nm}$ ), and vitamin $\mathrm{K}$ and hemin are required for growth. Carbohydrate fermentation is not detected with adonitol, cellobiose, fructose, glycogen, inositol, lactose, maltose, mannitol, rhamnose, salicin, starch, trehalose, or xylose, but fermentation of glucose, sucrose, sorbitol, galactose, and mannose usually occurs. Cells produce major amounts $(>10 \mu \mathrm{mol} / \mathrm{ml})$ of acetate, butyrate, and phenylacetate, and minor amounts $(<10$ $\mu \mathrm{mol} / \mathrm{ml}$ ) of isobutyrate and isovalerate are detected in cooked meat medium. Cells are catalase positive, liquefy gelatin, and have trypsin-like activity but do not produce lipase. $P$. macacae ATCC $33141^{\mathrm{T}}$ contains 13-methyltetradecanoic acid (iso- $\mathrm{C}_{15: 0}$ acid) as a major cellular fatty acid, and malate, glutamate, glucose-6-phosphate, and 6-phosphogluconate dehydrogenases are present. Strains have been isolated from oral cavities, subcutaneous abscesses, and pyothoraxes of animals, including cats and monkeys. P. macacae ATCC $33141^{\mathrm{T}}$ exhibits an average level of DNA-DNA hybridization with strains isolated from cats of $81 \%$ but no significant hybridization with other members of the genus Porphyromonas.

Consistent with the tight clustering of DNA-DNA hybridization values, $P$. macacae ATCC $33141^{\mathrm{T}}$ can be distinguished by phenotypic criteria from cat strains, suggesting that cat and monkey biovars exist. Members of cat and monkey biovars have different colonial morphologies on blood agar and produce different whole-cell protein and proteinase profiles on SDS-PAGE gels (Fig. 1). In addition, the cat biovar is lipase positive and produces glutamyl-glutamic arylamidase (3) but does not ferment sorbitol.

\section{ACKNOWLEDGMENTS}

This work was supported in part by the Australian Research Council.

The support, advice, and guidance of L. V. H. Moore and J. L. Johnson are very much appreciated. Hannele Jousimies-Somer provided the strain of $P$. macacae used and access to results from her laboratory, and these are gratefully acknowledged. G. Bailey provided the cellular fatty acid data for $P$. macacae ATCC $33141^{\mathrm{T}}$. D. Wigney provided bacteriological assistance. Prereduced media were prepared by L. Patoka.

\section{REFERENCES}

1. Collings, S., and D. N. Love. 1992. Further studies on some physical and biochemical characteristics of asaccharolytic pigmented Bacteroides of feline origin. J. Appl. Bacteriol. 72:529-535.

2. Coykendall, A. L., F. S. Kaczmarek, and J. Slots. 1980. Genetic heterogeneity in Bacteroides asaccharolyticus (Holdeman and Moore 1970) and proposal of Bacteroides gingivalis sp. nov. and Bacteroides macacae (Slots and Genco) comb. nov. Int. J. Syst. Bacteriol. 30:559-564.

3. Fournier, D., and C. Mouton. 1993. Phenotypic characterization of human 
and animal biotypes within the species Porphyromonas gingivalis. Res. Microbiol. 144:435-444.

4. Holdeman, L. V., E. P. Cato, and W. E. C. Moore (ed.). 1977. Anaerobe laboratory manual, 4th ed. Virginia Polytechnic Institute and State University, Blacksburg.

5. Johnson, J. L. 1985. DNA reassociation and RNA hybridization of bacterial nucleic acids. Methods Microbiol. 18:33-74

6. Karjalainen, J., A. Kanervo, M.-L. Vaisanen, B. Forsblom, E. Sarkiala, and H. Jousimies-Somer. 1993. Porphyromonas-like Gram-negative rods in naturally occurring periodontitis in dogs. FEMS Immunol. Med. Microbiol. 6:207-212.

7. Laemmli, U. K. 1970 . Cleavage of structural proteins during the assembly of the head of bacteriophage T4. Nature (London) 227:680-685.

8. Lambe, D. W., K. P. Ferguson, and W. R. Mayberry. 1982. Characterization of Bacteroides gingivalis by direct fluorescent antibody staining and cellular fatty acid profiles. Can. J. Microbiol. 28:367-374.

9. Love, D. N., G. D. Bailey, S. Collings, and D. A. Briscoe. 1992. Description of Porphyromonas circumdentaria sp. nov. and reassignment of Bacteroides salivosus (Love, Johnson, Jones, and Calverley 1987) as Porphyromonas (Shah and Collins 1988) salivosa comb. nov. Int. J. Syst. Bacteriol. 42:434 438.

10. Love, D. N., J. L. Johnston, R. F. Jones, and A. Calverley. 1987. Bacteroides salivosus sp. nov., an asaccharolytic, black-pigmented species from cats. Int. J. Syst. Bacteriol. 37:307-309.
11. Love, D. N., R. F. Jones, and M. Bailey. 1979. Clostridium villosum sp. nov. from subcutaneous abscesses in cats. Int. J. Syst. Bacteriol. 29:241-244.

12. Love, D. N., R. F. Jones, and A. Calverley. 1984. Description of asaccharolytic black-pigmented Bacteroides strains from soft-tissue infections in cats. Int. J. Syst. Bacteriol. 34:300-303.

13. Marmur, J., and P. Doty. 1962. Determination of the base composition of deoxyribonucleic acid from its thermal denaturation temperature. J. Mol. Biol. 5:109-118.

13a.Moore, L. V. H. Personal communication.

14. North, M. J., K. I. Scott, and B. C. Lockwood. 1988. Multiple cysteine proteinase forms during the life cycle of Dictyostelium discoideum revealed by electrophoretic analysis. Biochem. J. 245:261-268.

15. Paster, B. J., F. E. Dewhirst, I. Olson, and G. J. Fraser. 1994. Phylogeny of Bacteroides, Prevotella, and Porphyromonas spp. and related bacteria. J. Bacteriol. 176:725-732.

16. Selin, Y. M., B. Harish, and J. L. Johnson. 1983. Preparation of labeled nucleic acids (nick translation and iodination) for DNA homology and rRNA hybridization experiments. Curr. Microbiol. 8:127-132.

17. Slots, J., and R. J. Genco. 1980. Bacteroides melaninogenicus subsp. macacae, a new subspecies from monkey periodontopathic indigenous microflora. Int. J. Syst. Bacteriol. 30:82-85.

18. Tereba, A., and B. J. McCarthy. 1973. Hybridization of ${ }^{125}$ I-labeled ribonucleic acid. Biochemistry 12:4675-4679. 